\title{
Inducing Lodging Tolerance to Enhance Yield in Dicoccum Wheat using Potential Plant Growth Regulators
}

\author{
Sujatha M. Guled*, B.N. Aravinda Kumar, Ramesh Babu, \\ C.S. Hunshal and H. Venkatesh
}

Department of Agronomy, University of Agricultural Sciences, Dharwad, Karnataka, India

*Corresponding author

\begin{tabular}{|c|}
\hline Keywords \\
\hline $\begin{array}{l}\text { Lodging, Dicoccum } \\
\text { wheat, Plant growth } \\
\text { regulators and yield }\end{array}$ \\
\hline Article Info \\
\hline $\begin{array}{l}\text { Accepted: } \\
\text { xx November } 2018 \\
\text { Available Online: } \\
\text { xx December } 2018\end{array}$ \\
\hline
\end{tabular}

\section{A B S T R A C T}

An experiment was conducted to induce lodging tolerance for enhancing yield in dicoccum wheat varieties (Mudhol local and DDK-1029) using plant growth regulators (CCC at 500 and $1500 \mathrm{ppm}$ and Ethephon at 10, 20 and $30 \mathrm{ppm}$ ) during rabi seasons of 2009 and 2010 at Agricultural Research Station, Madhurkhandi, UAS Dharwad, Karnataka, India. The design of the experiment was randomized complete block design in factorial concept and replicated thrice. Among the two genotypes, the local variety 'Mudhol local' recorded significantly greater plant height $(84.9 \mathrm{~cm})$, stem length $(77.3 \mathrm{~cm})$, peduncle length $(30.1$ $\mathrm{cm})$. Whereas, DDK-1029 produced significant higher spikelets per panicle (16.6), number of grains per panicle (32.9), panicle length $(7.2 \mathrm{~cm})$, panicle weight $(85.2 \mathrm{~g})$ and test weight $(38.8 \mathrm{~g})$. Ethephon at $30 \mathrm{ppm}$ significantly reduced plant height $(70.3 \mathrm{~cm})$, stem length $(60.6 \mathrm{~cm})$ and yield $(270 \mathrm{~kg} / \mathrm{ha})$ but increased tillers $\left(390 \mathrm{~m}^{2}\right)$ test weight $(37.8 \mathrm{~g})$, grain and straw yield (449 kg/ha) and HI (42.3\%) which was closely followed by CCC at $1500 \mathrm{ppm}$. The interaction between growth regulator and genotypes showed that use of Ethephon at $30 \mathrm{ppm}$ resulted in significantly higher grain yield $(278 \mathrm{~kg} / \mathrm{ha})$, straw yield (396 kg/ha), panicle weight (92.0 g/ plant) and HI (47.5 \%) in DDK- 1029 than in Mudhol local.

\section{Introduction}

Wheat (Triticum spp.) a pretentious food grain in the feeding bowl to mankind occupies a premier position of all the staple food grain crops. It is grown around the world across a wide range of environments and more land is devoted to the production of wheat than any other crop. In India, bread wheat accounts for approximately 95 per cent of the wheat grown, while four per cent is durum wheat and one per cent is dicoccum wheat (Gupta, 2004). The dicoccum wheat is reported to have a high degree of resistance to rust diseases (stem and leaf rust) and terminal high temperature regimes and is valued in many countries for its higher grain quality. The dicoccum wheat like durum wheat is considered to be very suitable for preparation of semolina, vermicelli etc. These desirable traits of dicoccum wheat have been successfully used in inter-specific hybridization for improvement of aestivum and durum wheat. The cultivation of dicoccum wheat in Karnataka is very extensive in 
Belagavi, Vijayapura, Kalaburgi and Bidar districts under irrigated conditions. This type of wheat is preferred because of its adaptability to sowing periods and due to better quality traits.

Lodging is a complicated phenomenon that is influenced by many factors including wind, rain, topography, soil type, previous crop husbandry and disease. It is frequently associated with conditions that promote plant growth such as abundant supply of nutrients and water resulting in lanky growth of wheat stem making it prone to lodge at later stage (after heading) or during grain filling stage causing considerable yield loss. Lodging of dicoccum wheat was found to be more pronounced and was found to reduce the yield to about 30-40 per cent (Kelbert et al., 2004). Lodging may also adversely affect grain quality (Berry et al., 2003; Baker et al., 1998; Pinthus, 1973). In order to modify the stem, dicoccum wheat varieties were tried in this experiment with plant growth regulators CCC and ethephon exogenously that can regulate plant growth in numerous ways. This can alter source sink relation helping in more grains per ear and grain yield. Therefore, preventing, delaying or reducing lodging of cereals promote quantity, quality and harvest ability of grain and helps ensure a favorable economic outcome. Thus, an experiment was conducted to reduce lodging and to enhance the yield potential of improved and local variety of dicoccum wheat by using growth regulators.

\section{Materials and Methods}

The field experiment on inducing lodging tolerance to enhance yield in dicoccum wheat varieties using potential plant growth regulators (PGRs) during rabi seasons of 2009 and 2010 were conducted at Agricultural Research Station, Madhurkhandi. Factorial randomized block design with factor-I having two varieties (DDK- 1029 and Mudhol local) and factor-II having two anti-lodging plant growth regulators each at three concentrations and with conventional practice was adopted. Plant growth regulator CCC (2 chloroethyltrimethyl ammonium chloride) at 500, 1000 and $1500 \mathrm{ppm}$ and ethephon at 10, 20 and 30 ppm was applied at Feekes growth stage 9 (i.e., ligule of last leaf just visible).

The crop was sown using $150 \mathrm{~kg}$ seeds per ha with a spacing of $22.5 \mathrm{~cm} \mathrm{X} 10 \mathrm{~cm}$ and was applied with 30: 30: $20 \mathrm{NPK} \mathrm{kg} / \mathrm{ha}$ as basal dose. The top dressing with $30 \mathrm{~N} \mathrm{~kg}$ /ha was done at flower primordial initiation. Sowing was done on 25.11.2008 during first year and 01.10.2009 during second year, respectively. The gross and net plot size adopted was 22.5 $\mathrm{m}^{2}$ and $15.3 \mathrm{~m}^{2}$, respectively. The crop received an average rainfall of $384.3 \mathrm{~mm}$ with 35 rainy days during first year and $799.3 \mathrm{~mm}$ with 55 rainy days during second year. During the crop growth period the maximum temperature of 33.2 and $35.2{ }^{\circ} \mathrm{C}$ was observed in the month of March during first year and second year, respectively. The minimum temperature of 14.1 in January 2009 and 10.3 ${ }^{0} \mathrm{C}$ in December of 2010 was recorded. The remaining cultural operations viz., weeding, intercultivation, irrigation and plant protection measures were taken up as and when required. The crop was harvested on 26.03.2009 and 12.03.2010 during first and second year, respectively.

\section{Results and Discussion}

\section{Effect on growth parameters}

Controlling plant size in general and growth attributes viz., plant height, stem length, peduncle length and panicle length assume greater significance in reducing lodging of dicoccum wheat. Plant growth regulator $\mathrm{CCC}$ can achieve crop specific height control by inhibiting GA production early in the process 
and ethephon reduce apical dominance by releasing ethylene (Biro and Jaffe, 1984, Ota et al., 1975). In general plant growth regulators, irrespective of their levels decreased the plant height, stem length, peduncle and panicle length. Productive tillers were significantly higher in both the varieties compared to control (Table 1 and 2). The reduction compared to conventional practice may be attributed to PGRs impact at cellular level on plant physiological processes viz., reducing the plant height, stem length, shortening the upper most internodes and peduncle (Berry et al., 2000) and elongation retarding effect can be observed on tillers (Pendleton et al., 1969). PGR ethephon at 30 ppm resulted in significantly lower peduncle length in the variety DDK- $1029(26.0 \mathrm{~cm})$ compared to Mudhol local. The interaction effect though was non-significant resulted in numerically lower values of plant height $(80.2$ $\mathrm{cm})$, stem length $(70.6 \mathrm{~cm})$, peduncle length $(29.9 \mathrm{~cm})$ and panicle length $(6.8 \mathrm{~cm})$ compared to rest of the treatments and control $(86.9 \mathrm{~cm}, 79.7 \mathrm{~cm}, 31.8 \mathrm{~cm}$ and $8 \mathrm{~cm}$ for plant height, stem length, peduncle length and panicle length, respectively). Reduction in the plant height might have occurred on suppression of stem elongation by blocking GA production by CCC, reduced apical dominance by ethylene released by ethephon in leaves and this may be attributed to increased productive tiller number per meter row long and also per square meter area (Table 3). These results agree with the findings of Knapp and Harms (1988) and Rajala and Peltonen Sainio (2001). Further, Berry et al., (2004) demonstrated that application of chlormequat reduce the height of winter barley by 2-3 per cent, while ethephon could reduce height by 4-17 per cent.

Contribution of panicle number, number of filled spikelets, grain number and grain weight per panicle, thousand grain weight, assume greater importance in deciding the grain yield. The number of panicles per plant depends on number of productive tillers per plant. Panicle number alone may not decide the final grain yield (Table 6).

Number of spikelets per panicle (16.6) and number of grains per panicle (32.9) were significantly higher with variety DDK- 1029 compared to Mudhol local (Table 4) in both the years in general and over the years in particular. Among the plant growth regulators, ethephon at $30 \mathrm{ppm}$ resulted in significantly higher number of spikelets per panicle (17.5), number of grains per panicle (35.3) and thousand grain weight $(37.8 \mathrm{~g})$. Though, the interaction effects were statistically nonsignificant, ethephon at $30 \mathrm{ppm}$ was able to produce numerically higher number of spikelets (17.9) and grain number per panicle (35.4) and thousand grain weight (39.7) in the variety DDK- 1029 compared to Mudhol local (Table 4 and 5). Increase in the number of spikelets, grain number per panicle and thousand grain weight may be due to increased ear weight, increased panicle length and reduced peduncle length. The thousand grain weight could have also been due to higher rate of photosynthates assigned portioning to the grains or longer period of grain filling or both (Turk and Tawaha, 2002).

\section{Effect on yield parameters}

With respect to grain yield, between varieties DDK- 1029 recorded significantly higher grain yield (25.2 $\mathrm{q} / \mathrm{ha})$ compared to Mudhol local (20.9 q/ha) over the years. Among the plant growth regulators, ethephon at $30 \mathrm{ppm}$ recorded significantly higher grain yield (27 q/ha) compared to control (19.1 q/ha) and rest of the treatments over the years (Table 5). Further, variety DDK- 1029 with plant growth regulator ethephon at $30 \mathrm{ppm}$ resulted in significantly higher grain yield $(27.8 \mathrm{~kg} / \mathrm{ha})$ compared to Mudhol local (26.2 kg/ha). 
Table.1 Plant height $(\mathrm{cm})$ and stem length $(\mathrm{cm})$ of dicoccum wheat as influenced by genotypes and plant growth regulators at harvest

\begin{tabular}{|c|c|c|c|c|c|c|}
\hline \multirow{3}{*}{ Treatments } & \multicolumn{6}{|c|}{ Pooled (over two years) } \\
\hline & \multicolumn{3}{|c|}{ Plant height at harvest (cm) } & \multicolumn{3}{|c|}{ Stem length at harvest $(\mathrm{cm})$} \\
\hline & $\begin{array}{c}\text { Mudhol } \\
\text { Local }\end{array}$ & DDK 1029 & Mean & $\begin{array}{c}\text { Mudhol } \\
\text { Local }\end{array}$ & DDK 1029 & Mean \\
\hline CCC 500 ppm & 84.9 & 66.2 & 75.6 & 78.5 & 61.9 & 70.2 \\
\hline CCC 1000 ppm & 83.3 & 65.4 & 74.4 & $\mathbf{7 7 . 5}$ & 59.7 & 68.6 \\
\hline CCC 1500 ppm & 80.9 & 64.3 & 72.6 & 73.6 & 57.4 & 65.5 \\
\hline Ethephon-10 ppm & 86.5 & 65.9 & 76.2 & 78.6 & 61.5 & 70.1 \\
\hline Ethephon-20 ppm & 86.3 & 65.8 & 76.0 & 77.9 & 58.7 & 68.3 \\
\hline Ethephon-30 ppm & 80.2 & 60.4 & 70.3 & 70.6 & 57.6 & 66.6 \\
\hline Control & 86.9 & 66.6 & 76.6 & 79.7 & 62.7 & 71.0 \\
\hline Mean & 84.1 & 64.9 & 74.5 & 76.6 & 58.9 & 67.8 \\
\hline For comparing means of & $\mathrm{SEm} \pm$ & $\mathrm{CD}$ at $5 \%$ & & $\mathrm{SEm} \pm$ & $\mathrm{CD}$ at $5 \%$ & \\
\hline Genotype (G) & 0.3 & 1.2 & & 0.4 & 1.6 & \\
\hline Growth Regulator (GR) & 0.6 & 2.2 & & 0.7 & 2.9 & \\
\hline Interaction (G x GR) & 0.8 & 3.1 & & 1.1 & 4.1 & \\
\hline
\end{tabular}


Table.2 Peduncle length $(\mathrm{cm})$ \& Panicle length $(\mathrm{cm})$ of dicoccum wheat as influenced by genotypes and plant growth regulators at harvest

\begin{tabular}{|c|c|c|c|c|c|c|}
\hline \multirow[t]{3}{*}{ Treatments } & \multicolumn{6}{|c|}{ Pooled (over two years) } \\
\hline & \multicolumn{3}{|c|}{ Peduncle length $(\mathrm{cm})$} & \multicolumn{3}{|c|}{ Panicle length $(\mathrm{cm})$} \\
\hline & $\begin{array}{l}\text { Mudhol } \\
\text { Local }\end{array}$ & DDK 1029 & Mean & $\begin{array}{l}\text { Mudhol } \\
\text { Local }\end{array}$ & DDK 1029 & Mean \\
\hline CCC 500 ppm & 29.8 & 27.0 & 28.4 & 5.8 & 6.7 & 6.2 \\
\hline CCC 1000 ppm & 29.2 & 25.1 & 27.2 & 6.0 & 7.1 & 6.5 \\
\hline CCC 1500 ppm & 26.8 & 25.0 & 25.9 & 6.4 & 7.5 & 6.9 \\
\hline Ethephon-10 ppm & 31.7 & 28.6 & 30.1 & 6.0 & 6.5 & 6.3 \\
\hline Ethephon-20 ppm & 31.3 & 26.2 & 28.7 & 6.5 & 6.9 & 6.7 \\
\hline Ethephon-30 ppm & 29.9 & 26.0 & 27.9 & 6.8 & 7.0 & 6.9 \\
\hline Control & 31.8 & 29.3 & 30.6 & 8.0 & 8.8 & 8.4 \\
\hline Mean & 30.1 & 26.7 & 28.4 & 6.5 & 7.2 & 6.8 \\
\hline For comparing means of & $\mathrm{SEm} \pm$ & $\mathrm{CD}$ at $5 \%$ & & $\mathrm{SEm} \pm$ & $\mathrm{CD}$ at $5 \%$ & \\
\hline Genotype (G) & 0.2 & 0.9 & & 0.1 & 0.3 & \\
\hline Growth Regulator (GR) & 0.4 & 1.8 & & 0.1 & 0.6 & \\
\hline Interaction (G x GR) & 0.6 & NS & & 0.2 & NS & \\
\hline
\end{tabular}


Table.3 No of productive tillers of dicoccum wheat as influenced by genotypes and, plant growth regulators at harvest

\begin{tabular}{|c|c|c|c|c|c|c|}
\hline \multirow[t]{3}{*}{ Treatments } & \multirow{2}{*}{\multicolumn{3}{|c|}{$\begin{array}{c}\text { No of productive tillers/m row length } \\
\text { Pooled (over two years) }\end{array}$}} & \multirow{2}{*}{\multicolumn{3}{|c|}{$\begin{array}{c}\text { No of productive tillers } / \mathrm{m}^{2} \text { area } \\
\text { Pooled (over two years) }\end{array}$}} \\
\hline & & & & & & \\
\hline & $\begin{array}{c}\text { Mudhol } \\
\text { Local }\end{array}$ & DDK 1029 & Mean & $\begin{array}{l}\text { Mudhol } \\
\text { Local }\end{array}$ & DDK 1029 & Mean \\
\hline CCC 500 ppm & 95.8 & 76.0 & 85.9 & 393.0 & 310.0 & 351.5 \\
\hline CCC 1000 ppm & 99.8 & 82.5 & 91.2 & 416.0 & 337.0 & 376.5 \\
\hline CCC 1500 ppm & 106.0 & 84.6 & 95.3 & 420.0 & 354.0 & 387.0 \\
\hline Ethephon-10 ppm & 94.7 & 76.4 & 85.5 & 374.0 & 317.0 & 345.5 \\
\hline Ethephon-20 ppm & 99.0 & 84.8 & 91.9 & 385.0 & 365.0 & 375.0 \\
\hline Ethephon-30 ppm & 108.5 & 89.4 & 99.0 & 428.5 & 370.0 & 390.0 \\
\hline Control & 83.5 & 70.0 & 76.8 & 341.0 & 305.3 & 323.2 \\
\hline Mean & 98.2 & 80.5 & 89.4 & 393.9 & 336.9 & 365.4 \\
\hline For comparing means of & $\mathrm{SEm} \pm$ & $\mathrm{CD}$ at $5 \%$ & & $\mathrm{SEm} \pm$ & $\mathrm{CD}$ at $5 \%$ & \\
\hline Genotype (G) & 0.7 & 2.1 & & 8.4 & 28.0 & \\
\hline Growth Regulator (GR) & 1.4 & 5.5 & & 5.6 & 16.8 & \\
\hline Interaction (G x GR) & 2,0 & NS & & 8.0 & 24.0 & \\
\hline
\end{tabular}


Table.4 No of spikelets per panicle and grains per panicle of dicoccum wheat as influenced by genotypes and plant growth regulators at harvest

\begin{tabular}{|c|c|c|c|c|c|c|}
\hline \multirow[t]{3}{*}{ Treatments } & \multicolumn{6}{|c|}{ Pooled (over two years) } \\
\hline & \multicolumn{3}{|c|}{ Number of spikelets per panicle } & \multicolumn{3}{|c|}{ Number of grains per panicle } \\
\hline & $\begin{array}{c}\text { Mudhol } \\
\text { Local }\end{array}$ & DDK 1029 & Mean & $\begin{array}{c}\text { Mudhol } \\
\text { Local }\end{array}$ & DDK 1029 & Mean \\
\hline CCC 500 ppm & 14.9 & 15.8 & 15.3 & 29.5 & 31.1 & 30.3 \\
\hline CCC 1000 ppm & 15.6 & 16.1 & 15.9 & 29.7 & 32.2 & 30.9 \\
\hline CCC 1500 ppm & 16.8 & $\mathbf{1 7 . 8}$ & $\mathbf{1 7 . 3}$ & 32.0 & 35.6 & 33.8 \\
\hline Ethephon-10 ppm & 15.0 & 16.2 & 15.6 & 30.6 & 32.4 & 31.6 \\
\hline Ethephon-20 ppm & 16.3 & 17.4 & 16.9 & 31.4 & 34.2 & 32.8 \\
\hline Ethephon-30 ppm & 17.1 & 17.9 & $\mathbf{1 7 . 5}$ & 35.2 & 35.4 & 35.3 \\
\hline Control & 14.7 & 15.1 & 14.9 & 28.6 & 29.4 & 29.0 \\
\hline Mean & 15.7 & 16.6 & 16.2 & 31.0 & 32.9 & 32.0 \\
\hline For comparing means of & $\mathrm{SEm} \pm$ & $\mathrm{CD}$ at $5 \%$ & & $\mathrm{SEm} \pm$ & $\mathrm{CD}$ at $5 \%$ & \\
\hline Genotype (G) & 0.2 & 0.8 & & 0.3 & 1.2 & \\
\hline Growth Regulator (GR) & 0.4 & 1.6 & & 0.5 & 2.1 & \\
\hline Interaction (G x GR) & 0.6 & NS & & 0.7 & NS & \\
\hline
\end{tabular}


Table.5 Thousand grain weight (g) and grain yield of dicoccum wheat as influenced by genotypes and plant growth regulators at harvest

\begin{tabular}{|c|c|c|c|c|c|c|}
\hline \multirow[t]{3}{*}{ Treatments } & \multicolumn{6}{|c|}{ Pooled (over two years) } \\
\hline & \multicolumn{3}{|c|}{ Thousand grain weight (g) } & \multicolumn{3}{|c|}{ Grain yield $\left(\mathbf{q}\right.$ ha $\left.^{-1}\right)$} \\
\hline & $\begin{array}{l}\text { Mudhol } \\
\text { Local }\end{array}$ & $\begin{array}{c}\text { DDK } \\
1029\end{array}$ & Mean & $\begin{array}{c}\text { Mudhol } \\
\text { Local }\end{array}$ & $\begin{array}{l}\text { DDK } \\
1029\end{array}$ & Mean \\
\hline CCC 500 ppm & 32.9 & 38.2 & 35.6 & 17.8 & 23.2 & 20.5 \\
\hline CCC 1000 ppm & 33.1 & 39.2 & 36.1 & 18.5 & 23.9 & 21.2 \\
\hline CCC 1500 ppm & 34.0 & 40.5 & 37.3 & 21.6 & 26.2 & 23.9 \\
\hline Ethephon-10 ppm & 33.5 & 38.7 & 36.1 & 22.3 & 23.6 & 23.0 \\
\hline Ethephon-20 ppm & 35.1 & 39.3 & 37.2 & 22.8 & 25.0 & 23.9 \\
\hline Ethephon-30 ppm & 35.9 & 39.7 & 37.8 & 26.2 & 27.8 & 27.0 \\
\hline Control & 31.0 & 35.9 & 33.4 & 17.1 & 21.0 & 19.1 \\
\hline Mean & 33.7 & 38.8 & 36.2 & 20.9 & 25.2 & 23.1 \\
\hline For comparing means of & $\mathrm{SEm} \pm$ & $\mathrm{CD}$ at $5 \%$ & & $\mathrm{SEm} \pm$ & $\mathrm{CD}$ at $5 \%$ & \\
\hline Genotype (G) & 0.3 & 1.1 & & 0.2 & 0.9 & \\
\hline Growth Regulator (GR) & 0.5 & 2.1 & & 0.4 & 1.7 & \\
\hline Interaction (G x GR) & 0.8 & NS & & 0.6 & 2.5 & \\
\hline
\end{tabular}


Table.6 Panicle weight (g) of dicoccum wheat as influenced by genotypes and plant growth regulators at different stages of growth

\begin{tabular}{|c|c|c|c|c|c|c|}
\hline \multirow[t]{3}{*}{ Treatments } & \multicolumn{6}{|c|}{ Pooled (over two years) } \\
\hline & \multicolumn{3}{|c|}{ At initial flowering stage } & \multicolumn{3}{|c|}{ At mealy ripe stage } \\
\hline & $\begin{array}{c}\text { Mudhol } \\
\text { Local }\end{array}$ & DDK 1029 & Mean & $\begin{array}{c}\text { Mudhol } \\
\text { Local }\end{array}$ & DDK 1029 & Mean \\
\hline CCC 500 ppm & 60.6 & 72.0 & 66.3 & 73.4 & 83.8 & 78.6 \\
\hline CCC 1000 ppm & 66.8 & 76.5 & 71.6 & 84.6 & 86.6 & 85.6 \\
\hline CCC 1500 ppm & 71.5 & 84.4 & 77.9 & 88.8 & 90.4 & 89.6 \\
\hline Ethephon-10 ppm & 63.2 & 71.4 & 67.3 & 78.0 & 86.1 & 82.0 \\
\hline Ethephon-20 ppm & 66.1 & 73.9 & 70.0 & 84.2 & 88.7 & 86.5 \\
\hline Ethephon-30 ppm & 73.6 & 78.4 & 76.0 & 89.4 & 92.0 & 90.7 \\
\hline Control & 54.3 & 59.0 & 56.7 & 65.4 & 68.9 & 67.1 \\
\hline Mean & 65.1 & 73.7 & 69.4 & 80.5 & 85.2 & 82.9 \\
\hline For comparing means of & SEm \pm & $\mathrm{CD}$ at $5 \%$ & & $\mathrm{SEm} \pm$ & $\mathrm{CD}$ at $5 \%$ & \\
\hline Genotype (G) & 0.5 & 1.9 & & 0.5 & 1.9 & \\
\hline Growth Regulator (GR) & 0.9 & 3.6 & & 0.9 & 3.6 & \\
\hline Interaction (G x GR) & 1.3 & 5.1 & & 1.3 & 5.0 & \\
\hline
\end{tabular}


Table.7 HI (\%) and Fodder yield (q/ha) of dicoccum wheat as influenced by genotypes and, plant growth regulators at different stages of growth

\begin{tabular}{|c|c|c|c|c|c|c|}
\hline \multirow[t]{3}{*}{ Treatments } & \multicolumn{6}{|c|}{ Pooled (over two years) } \\
\hline & \multicolumn{3}{|c|}{ Fodder yield (q/ha) at harvest } & \multicolumn{3}{|c|}{ HI (\%) at harvest } \\
\hline & $\begin{array}{c}\text { Mudhol } \\
\text { Local }\end{array}$ & DDK 1029 & Mean & $\begin{array}{c}\text { Mudhol } \\
\text { Local }\end{array}$ & DDK 1029 & Mean \\
\hline CCC 500 ppm & 39.8 & 33.7 & 36.8 & 32.2 & 41.8 & 37.0 \\
\hline CCC 1000 ppm & 41.4 & 33.9 & 37.7 & 33.7 & 43.0 & 38.3 \\
\hline CCC 1500 ppm & 45.5 & 35.1 & 40.3 & 35.4 & 44.4 & 39.9 \\
\hline Ethephon-10 ppm & 45.9 & 35.2 & 40.6 & 32.3 & 42.2 & 37.2 \\
\hline Ethephon-20 ppm & 46.8 & 37.6 & 42.2 & 35.9 & 43.4 & 39.7 \\
\hline Ethephon-30 ppm & 50.3 & 39.6 & 44.9 & 37.5 & 47.1 & 42.3 \\
\hline Control & 36.2 & 34.7 & 35.4 & 32.0 & 39.3 & 35.6 \\
\hline Mean & 43.7 & 35.7 & 39.7 & 34.1 & 43.0 & 38.6 \\
\hline For comparing means of & $\mathrm{SEm} \pm$ & $\mathrm{CD}$ at $5 \%$ & & $\mathrm{SEm} \pm$ & $\mathrm{CD}$ at $5 \%$ & \\
\hline Genotype (G) & 0.4 & 1.6 & & 0.3 & 1.1 & \\
\hline Growth Regulator (GR) & 0.8 & 3.0 & & 0.5 & 2.0 & \\
\hline Interaction (G x GR) & 1.1 & 4.2 & & 0.7 & NS & \\
\hline
\end{tabular}


These results confirm the findings of Rajala and Peltonen Sainio (2001).

Harvest index is one of the most physiological traits for higher grain yield. Between varieties, DDK- 1029 recorded significantly higher harvest index (43\%) compared to Mudhol local (34.1 \%). Among growth regulators, ethephon at $30 \mathrm{ppm}$ produced significantly higher harvest index $(42.3 \%)$. Though the interaction effects were statistically non-significant, the variety DDK1029 recorded numerically higher harvest index $(47.1 \%)$ compared to Mudhol local (37.5\%) in response to the plant growth regulator ethephon at $30 \mathrm{ppm}$ (Table 7).

In conclusion, use of plant growth regulator ethephon at $30 \mathrm{ppm}$ resulted in reduction of growth factors like plant height, stems length and increased the grain yield and yield attributing characters in DDK- 1029 than Mudhol local.

\section{References}

Baker, C.J., Berry, P.M., Spink, J.H., Sylvester-Bradley, R., Griffin, J.M., Scott, R.K. and Clare, R.W., 1998. A method for the assessment of the risk of wheat lodging. J. Theor. Biol., 194, 587-603.

Berry, P. M., Griffin, J. M., SylvesterBradley, R., Scott, R. K. Pink, J. H. Banker, C. J. and Clare, R. W., 2000, Controlling plant form through husbandry to minimize lodging in wheat field. Crop Res., 67: 59-81.

Berry, P. M., Spink, J. H., Foulkes, M. J. and Wade, A., 2003, Quantifying the contributions and loses of dry matter from non- surviving shoots in four cultivars of winter wheat. Field Crops Res., 80: 111-121.

Berry, P. M., Sterling, M., Spink, J. H., Baker, C. J., Sylvester- Bradley, R.,
Mooney, S. J., Tams, A. R. and Ennos, A. R., 2004, Understanding and reducing lodging in cereals. $A d v$. Agron., 84: 217-271.

Biro, R. L. and Jalfe, M. J., 1984, Thigmomorphogenesis: Ethylene evaluation and its role in the changes observed in mechanically perturbed bean plants. Physiol. Plant, 62: 289296.

Gupta, R. K., 2004, Quality of Indian wheat and infrastructure for analysis. In: Joshi, A.K., Chand, R., Arun, B., Singh, G., (eds), A compendium of the training program (26-30 December, 2003) on wheat improvement in eastern and warmer regions of India: Conventional and non-Conventional approaches. NATP Project, (ICAR), BHU, Varanasi, India.

Kelbert, A. J., Spanner, D., Briggs, K. G. and King, J. R. 2004, Screening for lodging resistance in spring wheat breeding programmes. Plant Breeding., 123 (4): 349-354.

Ota Y., Nakayama M. and Akutsu T., 1975, Studies on the growth regulation of crop plants by mechanical stimulation (l). Dwarfing and ethylene production in several crop plants by mechanical stimulation. Proc Crop Soc Japan , 44: 181-182.

Pendleton, J. J. and Hammond, J. W., 1969. Relative Photosynthetic Potential for Grain Yield of Various Leaf Canopy Levels of Corn. Agron. J. 61: 911- 913.

Pinthus, M.J., 1973. Lodging in Wheat, Barley and Oats: the phenomenon, its causes and preventative measures. $A d v$. Agron. 25:210-263.

Rajala, A. and Peltonen-Sainio, P., 2001, Plant growth regulator effects on spring cereal root and shoot growth. Agron. J., 93: 936-943.

Turk, M. A. and Tawaha, A. M., 2002, Response of Winter Wheat to Applied 
$\mathrm{N}$ with or without Ethrel Spray under Irrigation planted in Semi-arid 464-466. Environments. Asian J. Plant Sci., 4:

\section{How to cite this article:}

Sujatha M. Guled, B.N. Aravinda Kumar, Ramesh Babu, C.S. Hunshal and Venkatesh, H. 2018. Inducing Lodging Tolerance to Enhance Yield in Dicoccum Wheat using Potential Plant Growth Regulators. Int.J.Curr.Microbiol.App.Sci. 7(12): 1895-1906. doi: https://doi.org/10.20546/ijcmas.2018.712.220 